\title{
Coastal Artificialization and Public Policies: The Example of the Beach of Marennes (Seudre Estuary, France)
}

\author{
Jonathan Musereau* and Hervé Regnauld*
}

\author{
Lab. COSTEL (LETG - UMR 6554 - CNRS, CAREN). Université de Rennes 2, Place du Recteur Henri Le Moal 35043 \\ Rennes Cedex, France
}

\begin{abstract}
This study deals with practical issues induced by public policies that have led to coastal artificialization. Problems of management of artificial coastal features are illustrated with the example of Marennes-Plage (French Atlantic Coast), a sand barrier built in 1997 to protect an artificial saltwater lagoon. This lagoon allows safe bathing at any time of the tide cycle and the sand barrier acts as a buffer against storm floods. But from now on, the sustainability of MarennesPlage becomes questionable and has shown signs of frailty. Present storm damages turn out to be more important than 10 years ago and the maintenance costs have dramatically increased. The main problem is to anticipate storms effects. Which storm is able to damage the sand barrier? When will it happen? To help the local managers we have built a tool for storm damage prediction : it is a locally tuned erosion index. This index is based on historical data, field work before and after storms and on online data (wind speed, waves, tides). It allows to sort out which combination of surge/wind speed and wave is likely to erode the artificial barrier. It also allows to anticipate the amount of lost material. This index has been tested for several storms and has proved its efficiency and its accuracy but in practice, the relevancy of our index will entirely depend of mitigation strategies and financial stakes. It could be efficient if managers get prepared for costly fast interventions on the dune/beach just before each damaging storm. It will not be really useful if replenishment is considered has a "one year time" event (just before tourists arrival) and low cost solution.
\end{abstract}

Keywords: Shore protection, beach nourishment, storm hazards, public policies.

\section{INTRODUCTION}

Studies focussing on morphological changes at sand barriers protecting artificial saltwater lagoon (i.e. man build beach and dune systems) are not very numerous, while an increasing number of such coastal features is observed in many countries. This work presents one case and aims at opening a wider discussion about these features because they are often under scrutiny from the local authorities as their maintenance cost is high and their sustainability is questionable. The case we study in this paper is located on the Gulf of Biscay (Fig. 1). Marennes-Plage is an artificial beach that has been built in order to satisfy political demands expressed by the local authorities, who wanted to develop tourism during the 70ies and 90ies. This beach has deeply modified the previous sedimentary cell, which was inherited from previous historical coastal works dating back to the $19^{\text {th }}$ century. Today the morphological behaviour of this beach is highly variable but severe phases of retreat and of sediment loss beg the question of the present sustainability of such an artificial feature. For the local managers the cost of sediment replenishment is so important that the question of the durability of the beach is openly at stake. Their main concern is to be able to anticipate the local effects of storms and to get prepared for fast intervention on the dune/beach. The scientific works they were asking for were about storm damage prediction and about mitigation strategies.

*Address correspondence to these authors at the Lab. COSTEL (LETG UMR 6554 - CNRS, CAREN). Université de Rennes 2, Place du Recteur Henri Le Moal 35043 Rennes Cedex, France;

E-mails: jonathan.musereau@club-internet.fr ; herve.regnauld@uhb.fr

\section{MATERIALS AND METHODOLOGY}

Marennes is located on the northern bank of river Seudre in the Département of Charente Maritime (Fig. 1). The city of Marennes, being on an estuary and not on the open ocean, is considered as a river city. During the last hundred of years, numerous devices were built to protect the coastal properties from hazards induced by storm events, as sand sheet, floods and others... (Fig. 2). During the mid $19^{\text {th }}$ century, a large forest of Pinus maritimus was planted on the dune system in order to stabilize it and to avoid sand sheets moving across neighbouring fields. In 1971, rocks blocks were set in front of the barrier system to prevent (uselessly of course) retreat. The side effects of rock armouring of dunes are well known [1] as they reverberate the waves and induce sand loss in front of them. The local authorities have tried to address this new problem of erosion and have built four groynes up drift of the beach in 1975. The sedimentary transit was slowed down but the beach didn't gain new material and was still very sensitive to storms. In 1985, the beach was virtually gone, the dune was eroded and each storm was by passing the dune remnants and creating floods. The local people decide to go for an artificial coast in 1997. The basis of the local economy is oyster-growing and the induced tourist activities such as restaurants and hotels. But there is no place for bathing if the tide is low. The aims of this new coastal device were three folded. First the new beach has to serve the local tourist-based economy and provide a good quality bathing area. Second it has to help rebuild the sea front of the city and to re shape its visual identity. Third it must be efficient against storm surges and associated floods. With a skilled political discourse, 


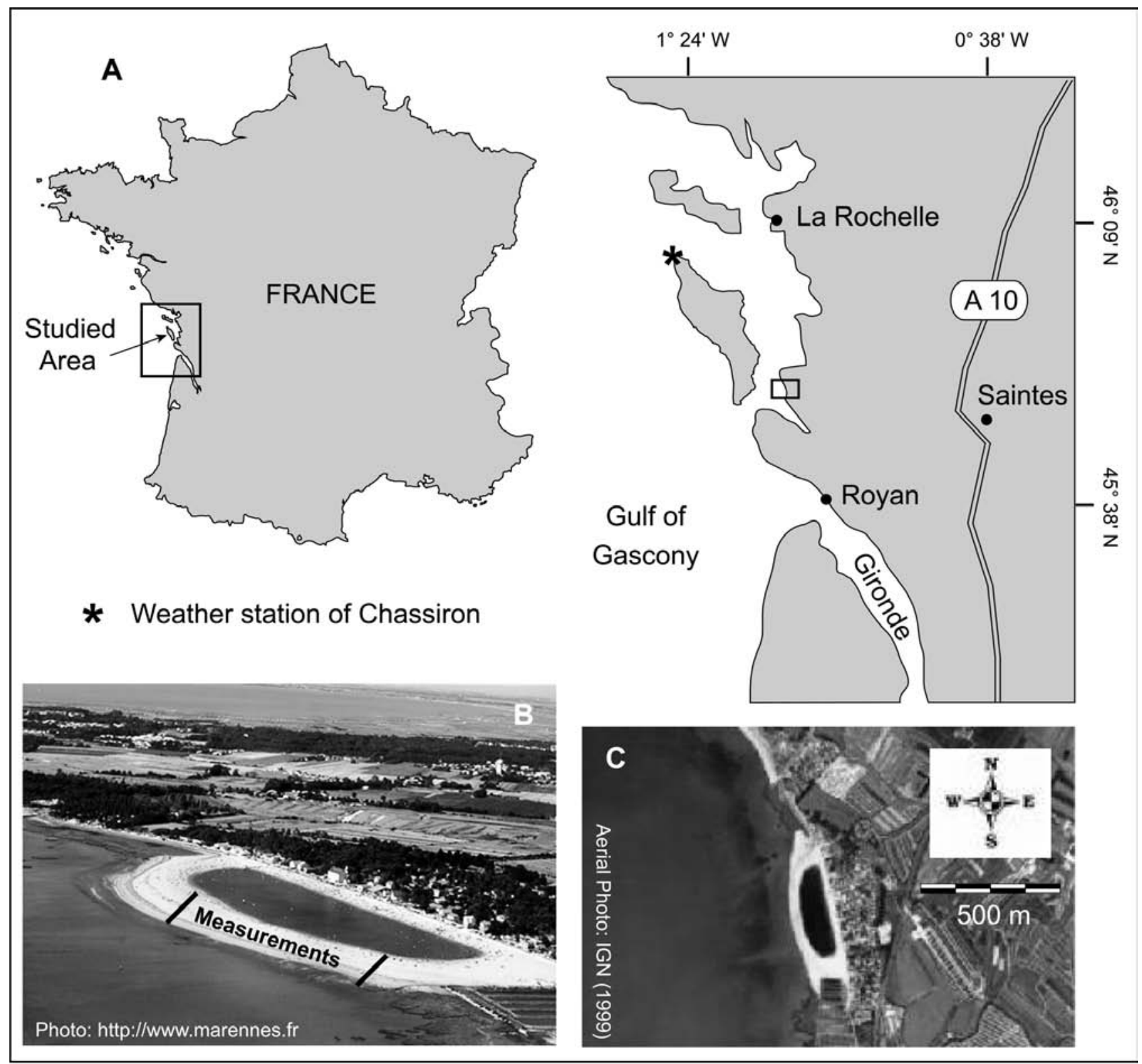

Fig. (1). The studied site. (A) General location. (B) Location of the topographic surveys. (C) Aerial photo of Marennes-Plage.

emphasizing this latest aspect the city succeeded in getting a grant from the French State and the local « region », which covered $65 \%$ of the total cost of the works. The most original part of the project is not in the new dune itself but in the fact that, behind it, a swimming area, as an enclosed body of salt water, is planned. The whole works have needed about $80.000 \mathrm{~m}^{3}$ of sand and the cost was of $800.000 €$. The new basin/dune/beach device has totally changed the face of the site. The coast line has been extended $150 \mathrm{~m}$ seaward; the beach is about $25 \mathrm{~m}$ wide. Against all odds the huge 1999 storm has not caused heavy damages [2]. However with the passing of years, the device encompasses a progressive decay. Wind blows sand from the dune into the swimming basin. Probably too much sand was moved because in the following years it began to by pass the swimming basin and to accumulate in the streets of the city. In 2001, to solve these unforeseen effects of aeolian dynamics due to the renourishment of the beach, the city has proceeded to a «brouettage ». As described by Marques et al. [3] through the example of Riells (Spain), this consists in the use of wheelbarrows to pick up sand which is scattered everywhere on roads, gardens, and to deposit it back on the dune. This is a way of involving the population into the task of dune rebuilding and to help them to express their concern. More recently, many reprofiling have been needed to maintain the shape of the sand barrier.

In spite of these actions, all observations confirm a decrease in the coastal work sustainability (see results below). Within that political frame our work has been to analyse the reasons of the beach/dune system decay and to propose some management solutions. The first assumption made by the local council was that erosion was due to some 


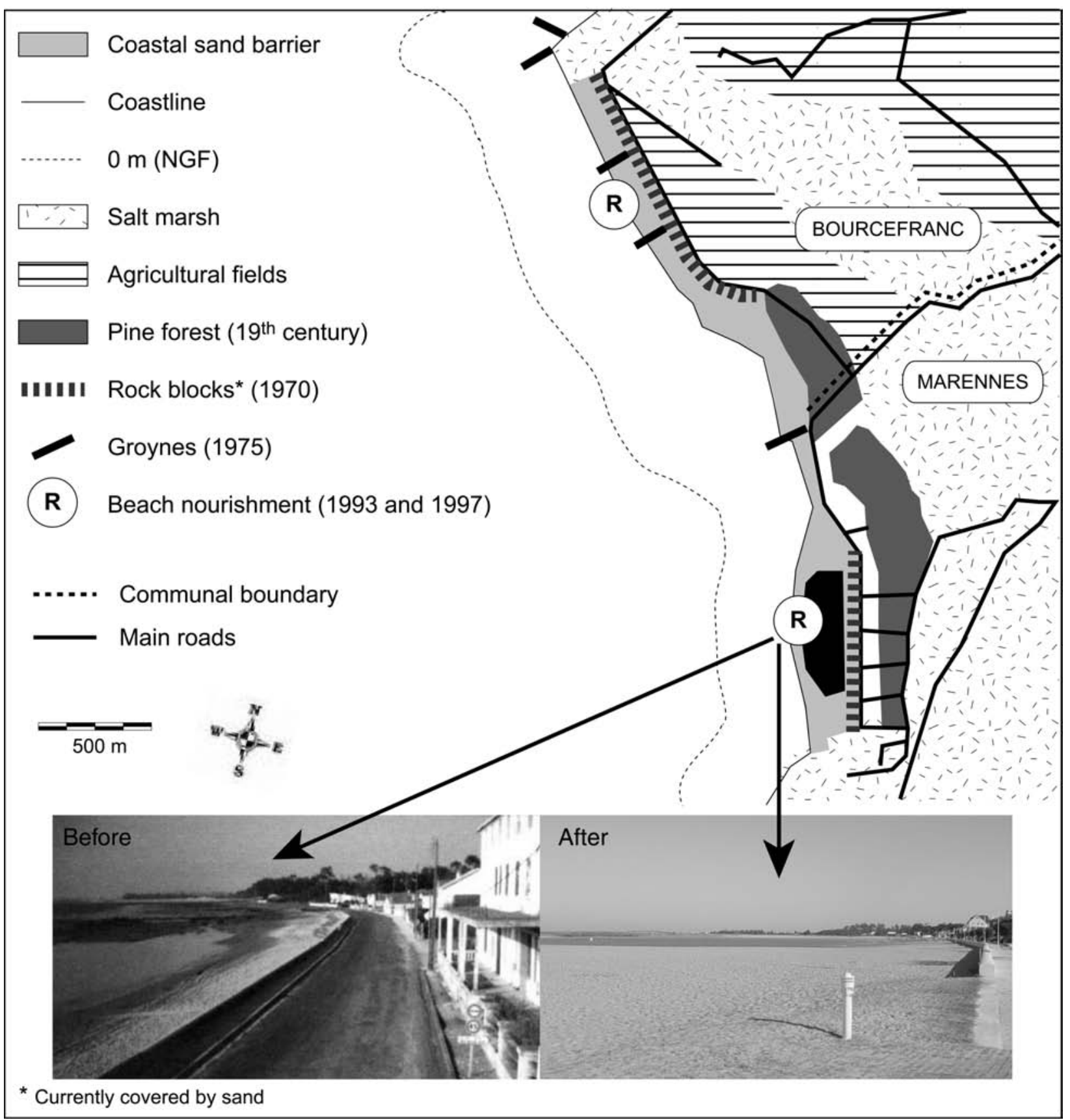

Fig. (2). Steps of the artificialization of the beach of Marennes since the $19^{\text {th }}$ century.

isolated events and not to average weather conditions. This assumption is based on local observations [4] and on many cases reported in the literature [5-7]. Our method was decided accordingly.

In the studied region, according to Meteo-France (Fig. 3), wind direction is annually balanced between SW (more frequent) and NE (less frequent) but western winds predominates when wind speed exceed $15 \mathrm{~m} . \mathrm{s}^{-1}$. Storms climatology [8], based on recorded mean wind speeds (10 minutes) between 1977 and 2003 at the weather station of Chassiron (source: Météo-France; location: north of Oléron island, see Fig. 1), shows a large inter-annual variability of storm hazards and does not provide any evidences for any trend in storm frequency. Though all storms do not create damages and only few of them are really erosive events.
Our method is derived from previous works dealing with indexes, thresholds and classification of storm impacts [9. 14]. We have a two folded approach. First we monitor coastal barrier morphology changes at a monthly scale and second, we cross it with local marine conditions (Fig. 4). Morphological changes are obtained out of field Digital Elevation Models calculated on the site. Field measurements were effective during two winter seasons: between October 2006 and March 2007 and then between October 2007 and March 2008. Meteo-marine data are obtained from a (near) real-time monitoring of storms, based on wind data from the GFS model (source: NOAA; coordinates: $5^{\circ} 93^{\prime} \mathrm{N}-1^{\circ} 30^{\prime}$ $\mathrm{W})$ and tide tables calculated by the French hydrographic and oceanographic institution (SHOM). 


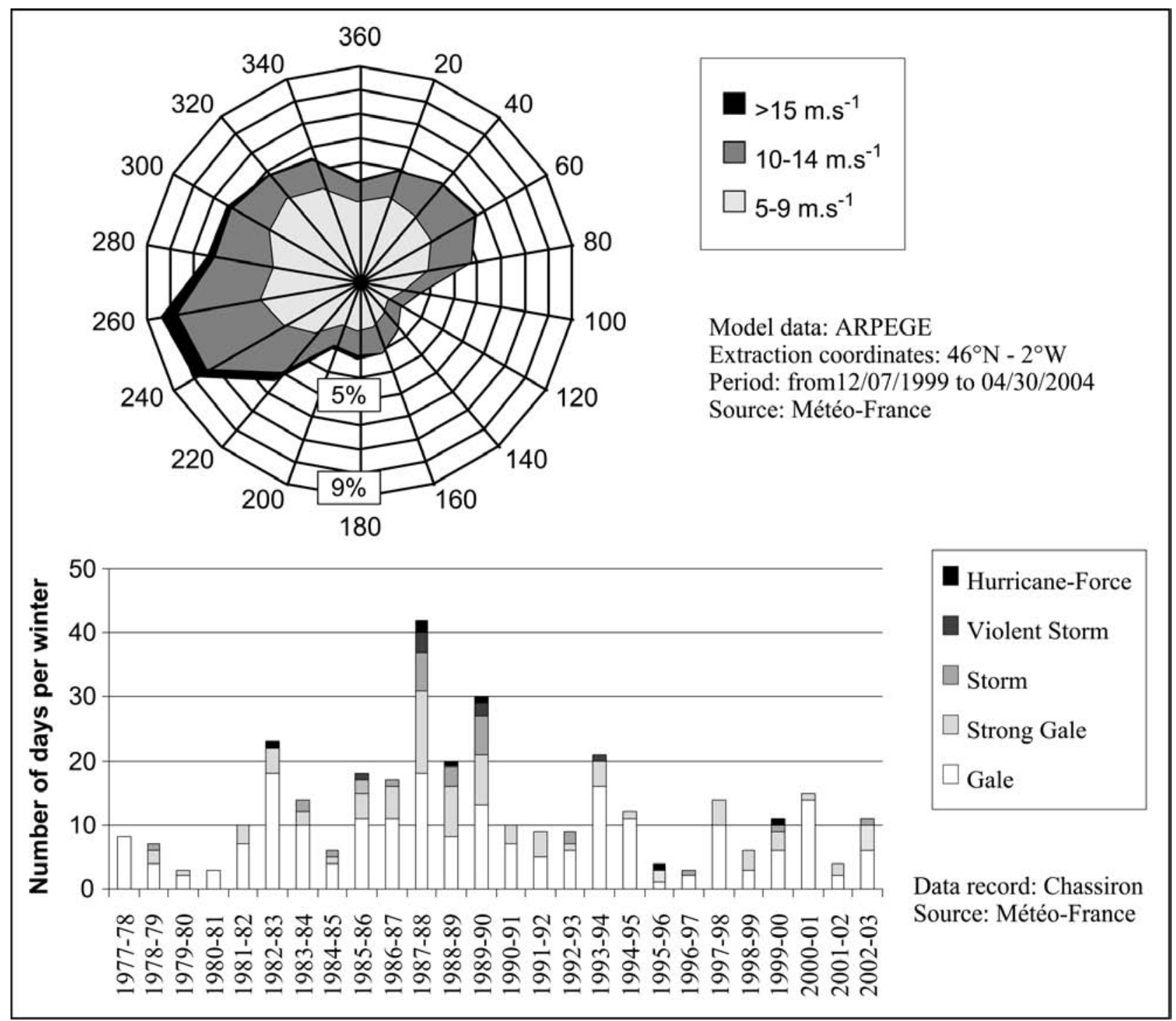

Fig. (3). Wind rose and storm climatology in the studied region.

By crossing erosive events and meteorological events, we can confirm the opinion of the local Council. The only storms which can produce erosion are those with a wind from the South West/North West sector and a high spring tide. From a purely statistical point of view this is true at a regional level, and would lead to a threshold based on a very simple addition of wind strength and water level (eq. 1), where SI is the index value, $f(v)$ a function of wind speed and $f(m)$ a function of tides.

$\mathrm{SI}=\mathrm{f}(\mathrm{V})+\mathrm{f}(\mathrm{M})$

This equation defines a storm index (SI) as it sorts out which storms may produce damage in the region but there is a need to understand the possible effects of local scale wave set-up and wave run-up on the erosive power of the storm. Therefore the wind data have to be calibrated to local conditions. Our monitoring of past events has allowed us to down scale the wind which is always slower on that site than off shore. The predicted tide level is up scaled to integrate wind set-up and wave run-up. It leads to a new equation (eq. 2 ), which is an erosion index (EI). The following parameters are used for its calculation: $\mathrm{V}$, average wind speed at $10 \mathrm{~m}$ $\left(\mathrm{m} . \mathrm{s}^{-1}\right) ;(\mathrm{V})^{\prime}$, filtering of non erosive directions; $\mathrm{M}$, predicted water level at high tide (m).

$\mathrm{EI}=0.5 \mathrm{~V}^{\prime}+\mathrm{M}^{1.46}$

This index varies from 18 to 28 . From a practical point of view, local managers also asked for results that are "easy to read". To make the index easier to use, a scale parameter of minus 8 is added. Thanks to this, the threshold that sorts out if the erosive event will or will not take place is 10 . Typically, low values of the index (less than 10 points) predict there is no effect; high values of the index (more than 10 points) forecast there will be an erosive event. Finally, after the measurement of several storm impacts, the review of the corresponding index values allows us to build a risk warning scale (Table 1).

$\mathrm{EI}=0.5 \mathrm{~V}^{\prime}+\mathrm{M}^{1.46}-8$ 


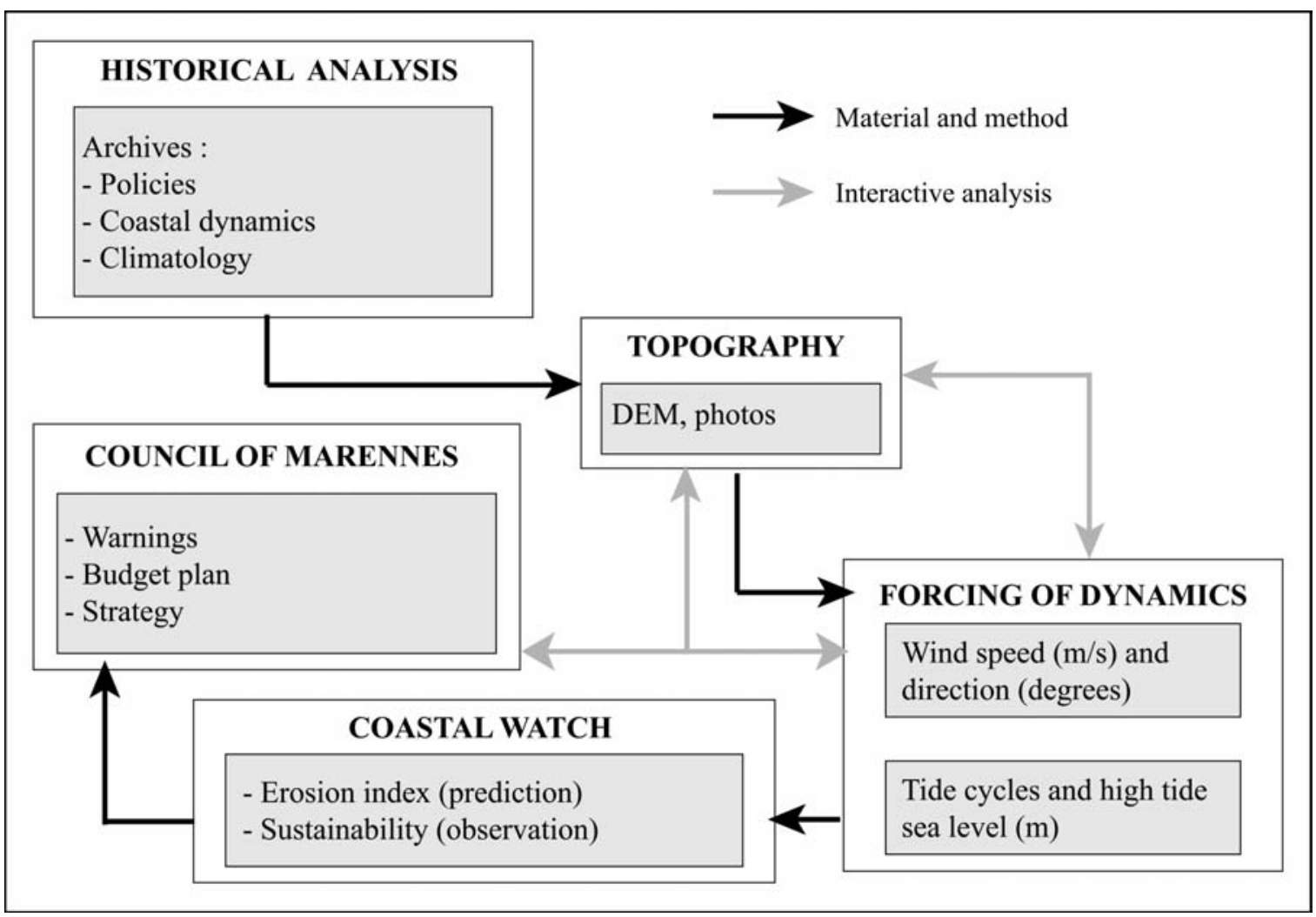

Fig. (4). Material and method developed in this study.

Table 1. A Proposed Scale for the Prediction of Damaging Storms (Erosion)

\begin{tabular}{|c|c|c|}
\hline Erosion Index & Level of Risk & $\begin{array}{c}\text { Expected Damage on the } \\
\text { Coastal Barrier }\end{array}$ \\
\hline \hline Less than 10 & Any & None \\
\hline 10 to 12 & Low & Limited dune recession \\
\hline 12 to 14 & Moderate & Significant dune recession \\
\hline 14 to 16 & High & Risk of breaches \\
\hline 16 and more & Very High & Complete overwashing \\
\hline
\end{tabular}

\section{RESULTS}

This section presents the results of the testing of the index between October 2006 and March 2008 and especially three predictions which have all been successful (12 09 2007, 310 2008, 1124 2008). Fig. (5) displays the history of the site between October 2006 and March 2008. In October 2006 the beach dune profile was smooth, reaching an altitude of $4 \mathrm{~m}$ AMSL. The sand volume on our test-site was of 6550 $\mathrm{m}^{3}$ (Fig. 5). No major change occurs before December 2006: a loss of about $1000 \mathrm{~m}^{3}$. In January the loss resumes and in February the local authorities move sand from the floor of the swimming basin and deposit it on top of the dune. In March (2007) the barrier looses sand but not enough to be considered as a threat. Though, about Christmas a new replenishment episode is needed. In March 2008 the barrier is breeched and all the sand which had been artificially brought in is taken back by the sea. It comes back slowly during the following months. The system is in a good condition when it is hit by the November (2008) storm.

Table 2 presents the prediction (and the results) for three recent storms. They occurred on December the $9^{\text {th }} 2007$, March the $10^{\text {th }} 2008$ and November the $24^{\text {th }} 2008$. According to the values recorded at the weather station of Chassiron, the first one was the most intense, with a maximum average wind speed of about $19 \mathrm{~m} . \mathrm{s}^{-1}$. The other storms were less powerful, with peak of wind reaching respectively 17 and 15 $\mathrm{m} . \mathrm{s}^{-1}$. However, the March the $10^{\text {th }} 2008$ is the only one that occurred during a high spring tide. Thus, according to our risk warning scale, the first storm should have only produced limited damages, the second a significant erosive event and the third should produce nothing (Table 2). Fig. (6) expresses how our index is highly efficient. Photos before and after each storm show the extend of the damages or their non existence. The December $9^{\text {th }}$ storm produced some erosion but not much, the March $10^{\text {th }}$ had large impacts, the November $24^{\text {th }}$ had none (Fig. 6). Damages couldn't be verified immediately after the storms but within a one week lapse of time, namely on the 12/16/2007, and 03/23/2008. These surveys indicate that the first storm has caused less than $1000 \mathrm{~m}^{3}\left(850 \mathrm{~m}^{3}\right)$ of losses in the surveyed area while the second caused a larger damage with losses reaching the double $\left(1800 \mathrm{~m}^{3}\right)$. In December, the reported retreat was around $1.5 \mathrm{~m}$ while it reached $3 \mathrm{~m}$ in March. We do not have any quantitative data about the third storm (November the $24^{\text {th }} 2008$ ) because there was no damage and no survey was asked for. Photos taken two days before $(11 / 22 / 2008)$ and 


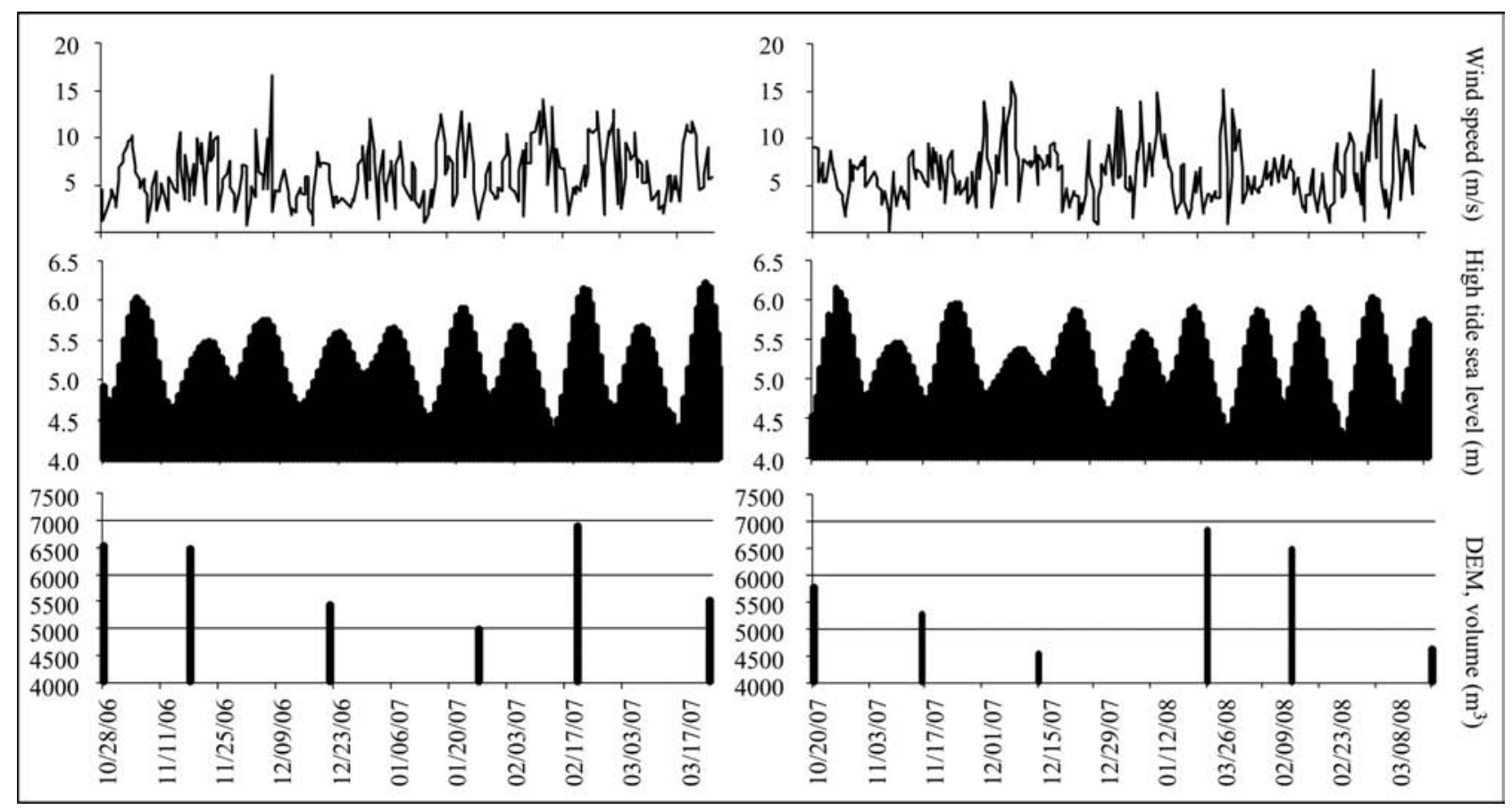

Fig. (5). Wind conditions, tide cycles and DEM volumes during the two surveyed winters.

after the storm (11/26/2008) are sufficiently clear to prove that almost nothing happened.

\section{DISCUSSION}

The city of Marennes now possesses an efficient tool which allows her to foresee the occurrence of the erosive events. The problem is to know if the city decides to foresee the planning of the coastal management works. Marennes is in front of two possible policies to manage the coastal barrier protecting the artificial swimming area (Fig. 7): a complete reshaping of the device or a set of small interventions if and when erosive storms occur. Obviously the first solution means that replenishment has to be considered every year (before tourists arrival) and has to be a single but large intervention. Conversely, the second solution involves the setting up of a coastal watch system and rests on several small interventions per winter (at each becoming storm which has a potential of erosion). In summary, the council has to select a strategy for Marennes-Plage. One could be considered as a "static solution" and the other as a "dynamic management" of the coastal barrier. An other problem is that, at a decadal time scale, no body actually knows how long an input of sand may last and when new replenishment will be needed. Many works have discussed this point and have not established a clear result [15-18]. Fig. (7) illustrates the choices that the local council has to face. Storm forced processes are represented inside of a rectangle caption, whereas societal responses are with an oval caption.

The first solution has a relatively low cost in working hours and a high cost in sand volume and may be planned far ahead as a yearly cost for the city expenditures. The problem is that it cannot cope with possible strong events that would occur during the winter. If a winter storm occurs and erodes sediment, the beach is less able to withstand low intensity storms and may loose more material. It means more sand will have to be added in summer. It cannot cope with a

Table 2. Examples of Storm Event and Induced Erosion Prediction

\begin{tabular}{|c|c|c|c|c|c|c|}
\hline \multicolumn{2}{|c|}{ Model Runs } & \multicolumn{2}{|c|}{ Predicted Event } & \multirow{2}{*}{$\begin{array}{l}\text { Predicted Impact } \\
\text { (Erosion Index) }\end{array}$} & \multirow{2}{*}{$\begin{array}{l}\text { Observed Impact } \\
\text { (Loss of Sand) }\end{array}$} & \multirow{2}{*}{$\begin{array}{l}\text { Maximum wind Speed } \\
\text { (10 Minutes) }\end{array}$} \\
\hline Date & Hour & Date & Hour & & & \\
\hline $\begin{array}{l}12 / 05 / 2007 \\
12 / 06 / 2007 \\
12 / 07 / 2007\end{array}$ & $\begin{array}{l}\text { 0h UTC } \\
\text { 0h UTC } \\
\text { 0h UTC }\end{array}$ & $12 / 09 / 2007$ & 18h UTC & $\begin{array}{l}11.5 \\
11.0 \\
11.1\end{array}$ & Limited & $19.4 \mathrm{~m} \cdot \mathrm{s}^{-1}$ \\
\hline $\begin{array}{l}03 / 06 / 2007 \\
03 / 07 / 2007 \\
03 / 08 / 2007\end{array}$ & $\begin{array}{l}0 \text { UTC } \\
0 \text { UTC } \\
0 \text { UTC }\end{array}$ & 03/10/2008 & 6h UTC & $\begin{array}{l}12.4 \\
12.8 \\
13.6\end{array}$ & Significant & $17.3 \mathrm{~m} \cdot \mathrm{s}^{-1}$ \\
\hline $\begin{array}{l}11 / 20 / 2007 \\
11 / 21 / 2007 \\
11 / 22 / 2007\end{array}$ & $\begin{array}{l}0 \text { UTC } \\
0 \text { UTC } \\
0 \text { UTC }\end{array}$ & $11 / 24 / 2008$ & Oh UTC & $\begin{array}{l}8.4 \\
9.0 \\
9.0\end{array}$ & Negligible & $14.9 \mathrm{~m} \cdot \mathrm{s}^{-1}$ \\
\hline
\end{tabular}



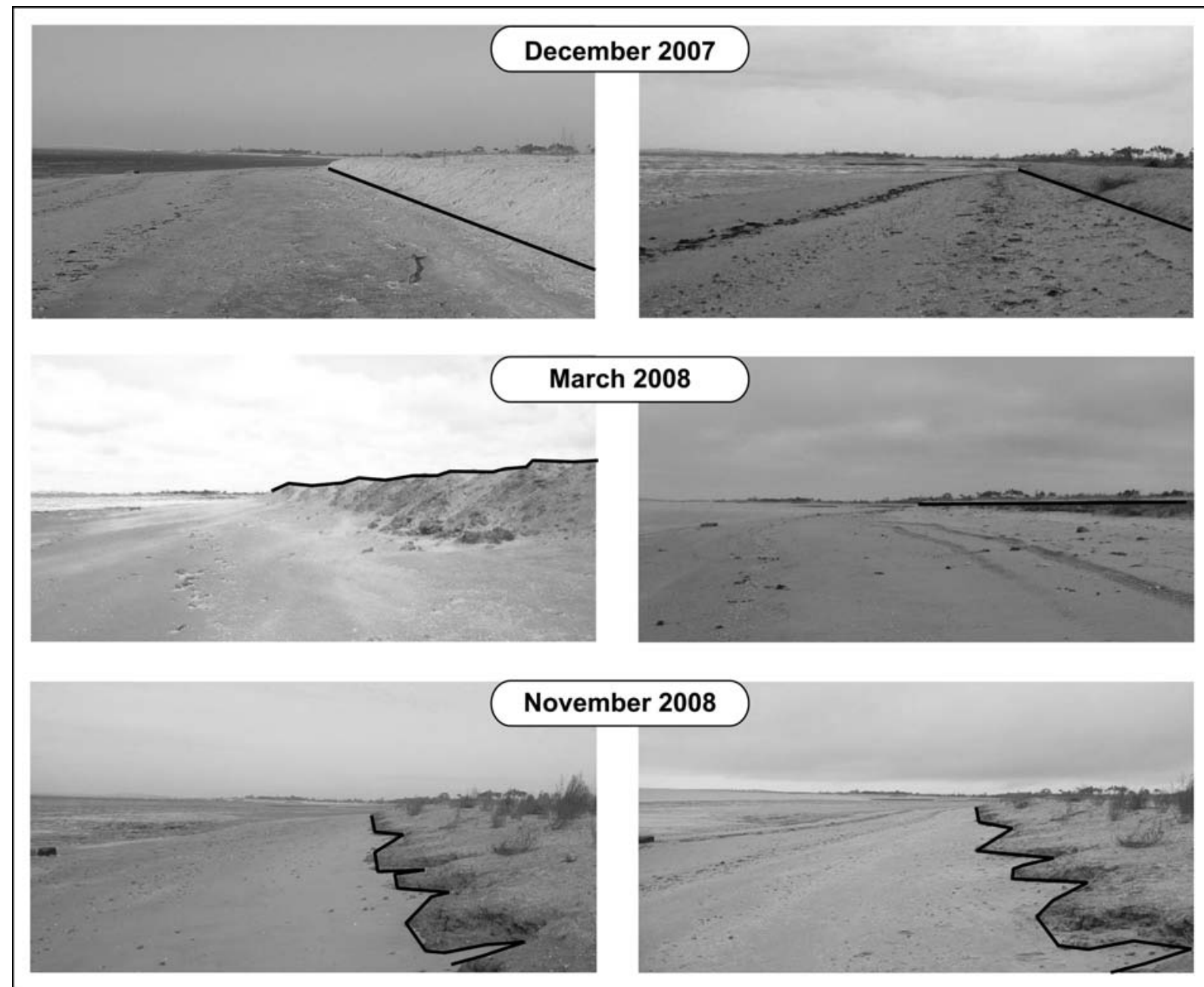

Fig. (6). Morphological changes caused by each predicted storm.

possible summer storm, which is very rare but may be very violent (such as in August 1978). The second policy is also highly questionable. The good points are the low cost (in sand volume) of each intervention; the wrong ones are that nobody knows how many interventions will be needed. The cost in working hours is unpredictable. A stormy year would be an expensive one; a fine weather year would be fine for the city finance. From a geomorphological point of view, some small sand inputs are better than a complete reprofiling of the beach/dune system. They imitate better the "natural" behaviour of the system and allow the beach profile to cope easily with low intensity storms. It helps it to be resilient [19-22]. After an erosive storm the barrier needs just a small amount of sand (in order to avoid water flowing through the gaps of the dune) and during the following fair weather episodes the sand will (hopefully) be moved back from the intertidal zone to the beach profile. If two storms follow each other the sediment doesn't come back. The best policy would be a mixture of small interventions when needed (i.e. in case of an erosive storm) and a late May, beginning of June, reprofiling for tourists. It is obviously too expensive for the city.

Marennes-Plage is really representative of how French engineers have been practicing beach nourishment until today:

\begin{abstract}
"Measures may be classified as remedial rather than preventive (...) In several cases, in situ tests have been performed to check the design. However, monitoring after nourishment is in most cases not systematic. The monitoring program is not planned in advance and is often not comprehensive" [23].
\end{abstract}

Up to today the device has a cost of $110^{6}$ Euros. After the 2008 local election, a new city council (from an other political side) has been elected. It openly questions the sustainability of the device. It asked the local population whether it was a good choice to mix two types of tourist activities (bathing on one hand, restaurants on the other). The local sedimentary and wave conditions do not favour the building of a very resilient beach/dune system. So the building of an artificial one may have been an excellent idea, but only if the city could finance its maintenance.

In this paper we have tried to link science to practice and, especially to public policies. This is not a simple task. French scientific works on this subject are not numerous, largely inspired by experiences from other countries (which are not systematically transposable) and are sometimes not well documented [24]. The relationship between applied science and management policies is largely dependant of 


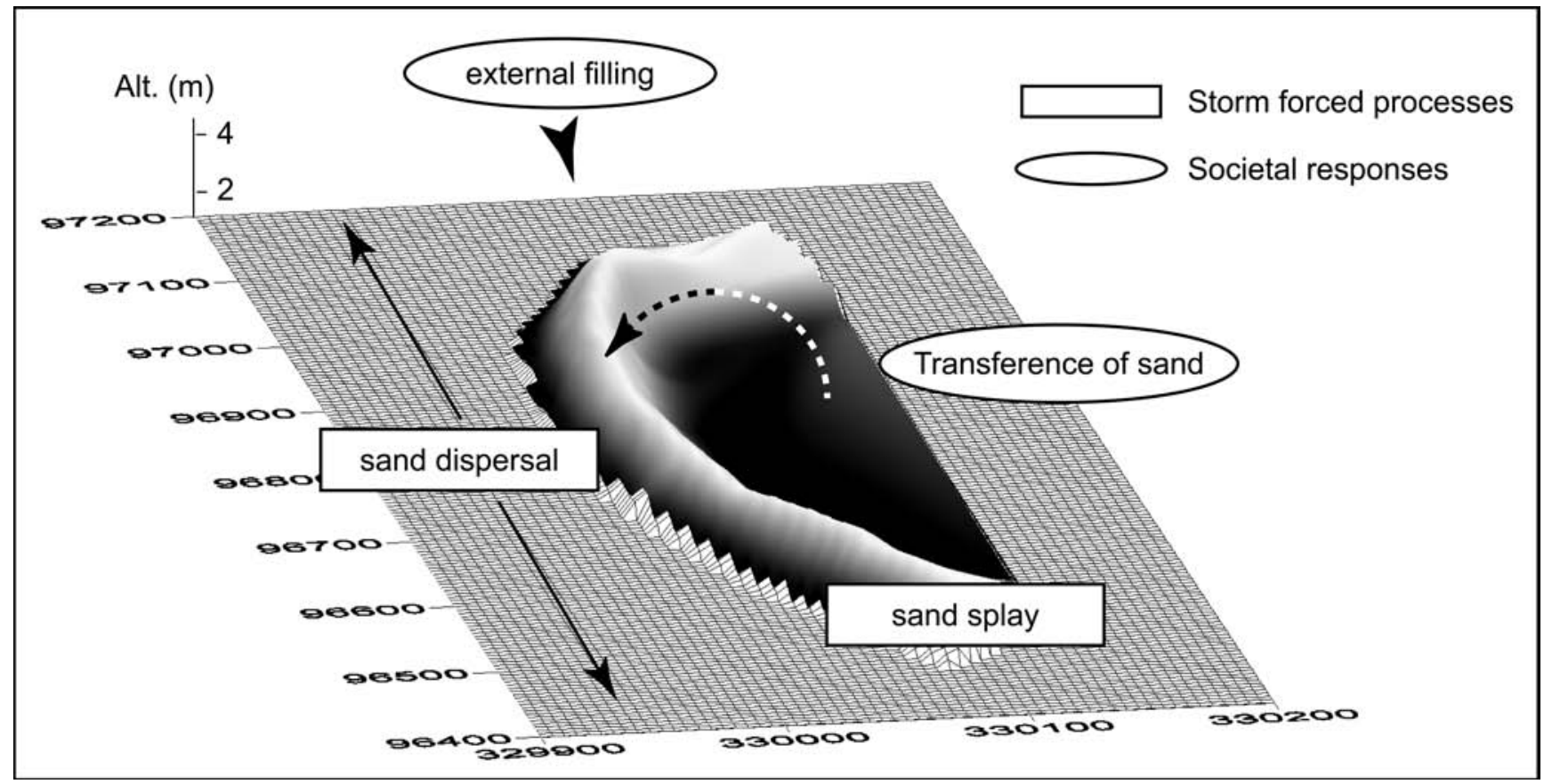

Fig. (7). Which policy for the managing of the coastal barrier protecting Marennes-Plage? Altitude: in meters NGF (Nivellement Général de la France, base level datum for maps in France); Geographic coordinates: Lambert II (French geodesic system), in meters also.

socio-historical and geographical contexts. In France, Geography as a scientific discipline dealing with coastal issues has considerably evolved during the past years. As mentioned by Pinot [25], this kind of mutation is most certainly induced by a complex set of changes related to the practice of science (becoming more technical, less descriptive and if possible with a precise applied goal) and dogma influencing how coastal areas must be managed ("good practices" decided by politicians). The nation-wide coastal act (1985) delivered by the state and its administrations is supposed to be locally applied everywhere. All over the country, the DATAR (Délégation à l'Aménagement du Territoire et à l'Action Régionale), renamed DIACT (Délégation Interministérielle à l'Aménagement et à la Compétitivité des Territoires) in 2006, is in charge of helping local bodies to fufill the requirements of good coastal management. It regularly produces a "code of good practices" translating the french philosophy at a given moment [26] into good management ideas. In practice, local adaptations are needed. The example of Marennes illustrates such a gap between state policies and local situations. After years of "hard" artificialization (block rocks, seawalls), and after seeing that it was a wrong way to solve the problem of coastal erosion at many localities, the French State has encouraged the development of "soft" solutions (beach replenishment and by-passing), notably by a financial contribution for relevant projects (the state may finance up to $60 \%$ of the local costs). So did Marennes shift from a hard solution (rock armour) to a soft one (artificial sand barrier). The problem is that local conditions are changing: the city council has shifted from the right wing to the left wing and the cost of sand replenishments has raised. Currently, the council of Marennes is in a perilous situation.
Its local managers feel that they have been cheated by the state. No financial help in time of need is planned and nobody warned them that the soft coastal feature they built could be so costly to maintain.

\section{CONCLUSION}

Artificial coast lines are very often designed for tourism. As Sutton and Bushnell [27] have explained it for artificial reefs, new coasts mean new management issues. Following the results of the European Program "Corine Coastal Erosion" [28], the present trend along the French coast is likely to see an increase in the coastline retreat (with a maximum of 35 meters per year at the exposed beach of Arvert, ten kilometers to the West from Marennes). The likely economical trends are not making the local authorities optimistic about their capacity to raise large amount of money for endangered beaches. Mitigation is supposed to be the best policy [29]. Benson and Twigg [30] have also shown that anticipation of crisis is the best solution. A largely unknown issue is the cost which is difficult to properly evaluate. For local communities such as Marennes, with limited money, there is a temptation to simply abandon parts of the coastlines which have been artificialized just because of their costs. It is an important issue to know whether this is the most frequent response to present coastal problems or if other solutions may be though of.

\section{REFERENCES}

[1] Kraus NC. The effects of seawalls on the beach: an extended literature review. J Coast Res 1988; SI 4: 1-28.

[2] Brulay F, Pupier-Dauchez S. From Marennes to marennes-plage, the management of a mud-flat. C Biol Mar 2006; 47(1): 79-84. 
[3] Marques MA, Psuty NP, Rodriguez R. Neglected effects of aeolian dynamics on artificial beach nourishment: the case of riells, Spain. J Coast Res 2001; 17(3): 694-704.

[4] Musereau J, Regnauld H, Planchon O. Vulnérabilité aux tempêtes des dunes littorales : développement d'un modèle de prédiction du dommage à travers l'exemple de Saint-Trojan (Ile d'Oléron, France). Annal Assoc Int Climatol 2007; 4: 145-66.

[5] Ruggiero P, Komar PD, Marra JJ, McDougal WG, Beach RA. Wave runup, extreme water levels and the erosion of properties backing beaches. J Coast Res 2001; 17(2): 407-19.

[6] Morton RA, Sallenger HA. Morphological impacts of extreme storms on sandy beaches and barriers. J Coast Res 2003; 19(3): 560-73.

[7] Regnauld H, Pirazzoli PA, Morvan G, Ruz M. Impacts of storms and evolution of the coastline in western France. Marine Geol 2004; 210(1-4): 325-37.

[8] Pirazzoli PA. Surges, atmospheric pressure and wind change and flooding probability on the Atlantic coast of France. Oceano Acta 2000; 23: 643-61.

[9] Allen JR. Beach erosion as a function of variations in the sedimentary budget, Sandy Hook, New Jersey, USA. Earth Surf Land 1981; 6: 139-50.

[10] Balsillie JH. Beach and coast erosion due to extreme event impact. Shore and Beach 1986; 54(4): 22-37.

[11] Dolan R, Davis R. An intensity scale for Atlantic Coast northeast storms. J Coast Res 1992; 8(4): 840-53.

[12] Kriebel D, Dalrymple R, Pratt A, Sakovich V. A shoreline risk index for northeasters, ASCE: Conference Proceedings. International conference on Natural Disaster Reduction. Washington, DC 1997; pp. 251-52.

[13] Sallenger AH. Storm impact scale for barriers islands. J Coast Res 2000; 16(3): 890-95.

[14] Zhang K, Douglas BC, Leatherman SP. Beach erosion potential for severe nor'easters. J Coast Res 2001; 17(2): 309-21.

[15] Davis RA, Wang P, Silverman BR. Comparison of the performance of three adjacent and differently constructed beach nourishment projects on the gulf peninsula of florida. J Coast Res 2000; 16(2): 396-407.

[16] Browder AE, Dean RG. Monitoring and comparison to predictive models of the Perdido Key beach nourishment project, Florida, USA. Coast Eng 2000; 39(2-4): 173-91.

[17] Capobianco M, Hanson H, Larson M, et al. Nourishment design and evaluation: applicability of model concepts. Coast Eng 2002; 47(2): 113-35.

[18] Nordstrom KF, Jackson NL, Bruno MS, De Butts HA. Municipal initiatives for managing dunes in coastal residential areas: a case study of Avalon, New Jersey, USA. Geomorphology 2002; 47(24): $137-52$

[19] Verhagen HJ. Method for artificial beach nourishment, American Society of Civil Engineering: Conference proceedings. New York 1992; pp. 2474-85.

[20] Dobroniak C, Anthony EJ. Short-term morphological expression of dune recycling on a macrotital, wave-exposed estuarine shoreline. J Coast Res 2002; SI36: 240-8.

[21] List JH, Farris AS, Sullivan C. Reversing storm hotspots on sandy beaches: Spatial and temporal characteristics. Mar Geol 2006; 226(3-4): 261-79.

[22] Claudino-Sales V, Wang P, Horwitz MH. Factors controlling the survival of coastal dunes during multiple hurricane impacts in 2004 and 2005: Santa Rosa barrier island, Florida. Geomorphology 2008; 95(3-4): 295-315.

[23] Hanson H, Brampton A, Capobianco M, et al. Beach nourishment projects, practices, and objectives - a European overview. Coast Eng 2002; 47(2): 81-111.

[24] Pupiez-Dauchez S. Le rechargement sédimentaire des plages vendéennes et charentaises: vers une gestion globale du littoral ? Proceedings of the international pluridisciplinary conference "The littoral: challenge, dialogue, action. France: Lille 2008.

[25] Pinot J-P. Géographie des littoraux en France: évolution d'une discipline. In: Rue d'ULM, Ed. Le littoral: regards, pratiques et savoirs. Paris: Fondation de l'Ecole Normale Supérieure 2007; pp. 27-58.

[26] Le Pape E. L'aménagement du littoral. DATAR: Paris, La Documentation Française 1993

[27] Sutton SG, Bushnell SL. Socio-economic aspects of artificial reefs: Considerations for the great barrier reef marine park. Ocean Coast Manage 2007; 50(10): 829-46.

[28] Service contract B4-3301/2001/329175/MAR/B3. Coastal erosion Evaluation of the need for action. Directorate General Environment European Commission, Brussels, Belgium. [Retrieved 2004 May 29]. Available from: http://www.eurosion.org/reports-online/part2. pdf

[29] Rohr E, Psuty NP. Coastal Dunes: a mitigation approach to the effects of coastal storms, The Coastal Society: Conference Proceedings. Minding the Coast: It's Everybody's Business. Williamsburg, Virginia 1998; pp. 154-60.

[30] Benson C, Twigg J. Measuring mitigation: methodologies for assessing natural hazard risks and the net benefits of mitigation - a scoping study. Provention Consortium, Geneva, Switzerland. [Retrieved 2004 December]. Available from: http://www.provent ionconsortium.org/themes/default/pdfs/MM_synthesis.pdf

(C) Musereau and Regnauld; Licensee Bentham Open.

This is an open access article licensed under the terms of the Creative Commons Attribution Non-Commercial License (http://creativecommons.org/licenses/by$\mathrm{nc} / 3.0 /$ ) which permits unrestricted, non-commercial use, distribution and reproduction in any medium, provided the work is properly cited. 